した。細部に就てはこつでは申述べない。

この報告までの経過は未だ治潦の途中であり，倘お 手術すべき妈が残つて居るが, 最近の写真を「スライ ド」で示す。(写真略)

第 1 例では眼臉外反に対しては満足な結果が得ら． れ, 開口, 閉口運動, 形部運動等の改善が 認められ た。

第 2 例では瘢痕が広範囲で深く, 術後「ハロイド」 を造る傾向があり，仲々良好な成績が得られなかつた。 左下眼瞼に就ては 3 度の埋没植皮を必要とし, 一応の 目的を達成した。開口障碍も相当の改善は得たが，充 分とは云えない。

倫扮両症例共, 外耳款の大部分が缺損して居り, 従 つて造耳術についても今後研究の上で実施してみたい と思つて居る。
結 論

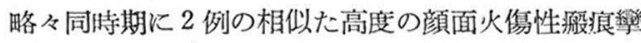
縮の 2 例を経験し，現在まで第 1 例で 7 回，第 2 例で

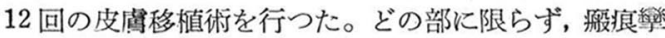
縮の治燎は難しいものと昔から云われて居るが, 顔面 にあつては特にその感を深く致しました。医師，患者 共に多大の忍耐と努力を必要とするのであるが，私の 考えでは治潦を投げ出すのは主として医師の側にある 嵄に考えられる。常に患者と共に努力する気慨が必要 であると思う。

私の行つた方法は必ずしも最良の方法とは云えない し, よりよい植皮方法の探求が勿論必要である。それ と共に技術面に於ける充分なる習熟と云うことも，特 に必要であるということを痛感した。

\title{
麦杊り前後の春柱可動性の観察
}

\author{
福岡県三渚郡大町 国武博紀
}

\section{Observation on Spinal Mobility before and after Wheat-Harvesting}

By

\author{
H. Kunitake \\ Öki, Fukuoka-ken
}

\section{緒}

言

脊柱の生理及び病理を対象とする場合に，その可動 性が最も基礎的問題であることは論を待たぬ所であ る。従つて古来幾多の脊柱運動描写器が考案されてい るが，日常臨床上に使用されることの少いのは之等の 器具の複雓性に依ると考光られる。

久留米大学, 整形外科教室では日常臨床上に脊柱の 形状, 可動性の観察, 描写等の為めに曲線定規を使用 して居られるが，私は宫城教授の指導により $2 ， 3 の$ 基礎的計測を行い，之を応用して麦刈前後の脊柱可動 性の変化を観察したので其の結果を報告する。

\section{測定法}

図 1. 長さ $80 \mathrm{~cm}$ の市販の曲線定規（以下単に定規

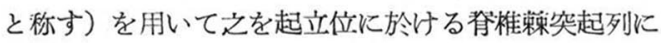

当て指頭を以て定 規をよく適合させ る。此の際に定規 の不橈部を仙骨に 当て〉第 5 腰椎, 第 12 胸椎, 第 7 頸 椎部に印を附して おく。前屈及後屈 の場合も同様に行 5 。図 2 . 斯 $<し$ て脊柱に沿5粼曲 を生ぜしめた定規 を静かに黒板上に 置き, 白墨で脊柱 の曲線を描き, 不

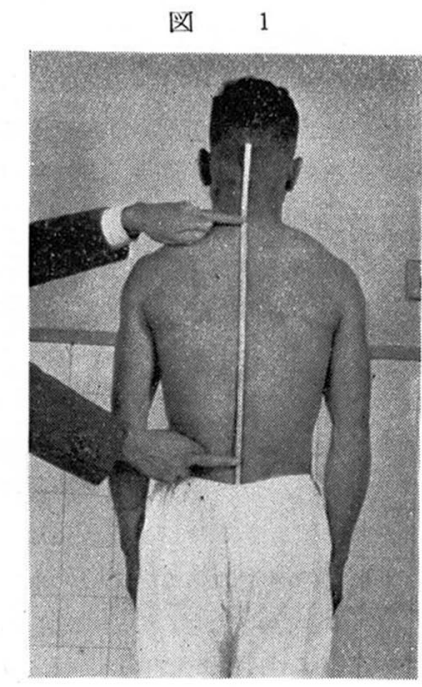




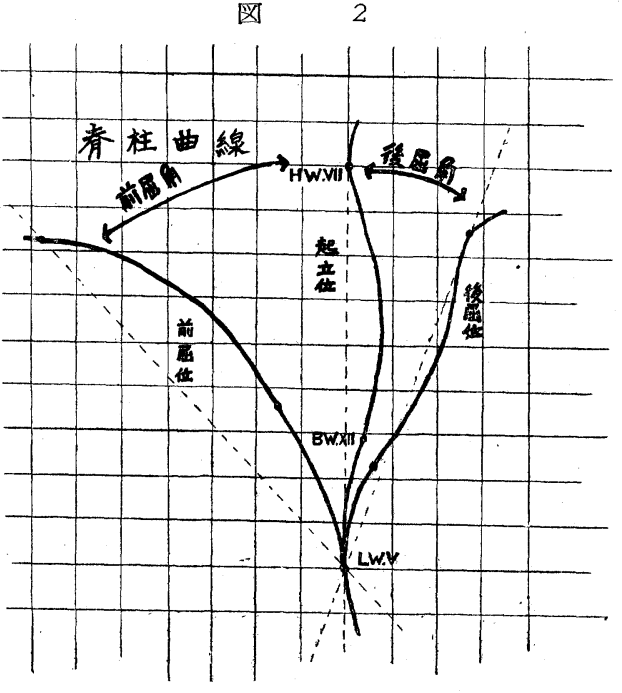

橈部即ら似骨及び第 5 腰椎部で重ね合せて起立位, 前 及び後屈時の曲線を描く。之を方眼紙上に縮小乙て計 測に用らる。

測 定 值
1. 測定誤差について
以上の様にして描写した脊柱の曲線は脊椎列のどの 部分を，どの程度の偏異を以て現わしているかを知 るために成人 10 名学童 10 名計 20 名について, 定規 を梀突起列に当てて正確にレ線側面像をとつて検討し た。表 1 に示す様に第 6 胸椎, 第 12 胸椎更び第 4 腰 椎部で比較すると定規で描く曲線は椎体前縁を結ぶ曲 線に近く，後縁を結ぶ曲線とはや〉誤差が大となる。 又運動侍の誤差は表 2 の如く第 12 胸椎部で最も誤差 を生じ易いがその誤差は僅少であつて略々一定してい るので曲線定規は脊柱の前後屈運動の具体的表現のた めには臨片上有用, 簡便な方法と言える。

2. 麦朾り前後の脊柱可動性について
表 1

椎体と定规と口距離

\begin{tabular}{|c|c|c|c|c|c|}
\hline & & & \multicolumn{2}{|c|}{ 学童 10 名 } \\
\hline & & 前緣 & 後緣 & 前緣 & 後緣 \\
\hline \multirow{3}{*}{ 胸 椎 $\mathrm{M}$} & 起立位 & 10.0 & 6.7 & 7.6 & 5.0 \\
\hline & 前屈 位 & 9.7 & 6.4 & 7.4 & 4.8 \\
\hline & 後屈位 & 10.0 & 6.7 & 7.5 & 4.9 \\
\hline \multirow{3}{*}{ 胸 椎 XII } & 起立位 & 10.4 & 6.7 & 8.1 & 5.0 \\
\hline & 前 屈 位 & 10.0 & 6.2 & 8.0 & 5.8 \\
\hline & 後 屈 位 & 10.3 & 6.6 & 8.2 & 5.1 \\
\hline \multirow{3}{*}{ 腰 椎 IIII } & 起 立. 位 & 12.0 & 7.7 & 9.8 & 6.5 \\
\hline & 前 屈 位 & 11.8 & 7.5 & 9.7 & 6.5 \\
\hline & 後屈位 & 12.1 & 7.9 & 9.9 & 6.7 \\
\hline
\end{tabular}

表 2

\begin{tabular}{|c|c|c|c|c|c|}
\hline & & \multicolumn{4}{|c|}{ 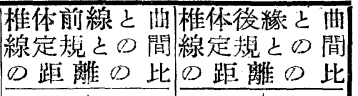 } \\
\hline 椎骨名 体 & 起立位 & 前属位 & 後属位 & 前屈位 & 後属 \\
\hline 胸 & 100 & 97.0 & 99.4 & 95.3 & 100.1 \\
\hline 椎 & 100 & 95.8 & 99.2 & 92.2 & 99.0 \\
\hline 椎 & 100 & 99.8 & 101.2 & 97.8 & 102.7 \\
\hline
\end{tabular}

（1）測定人員並びに測定法

今年の麦刈持に, 就業前即ら午前 5 時より 8 時汽の 間で測定し，夕刻帚宅㭙午後 6 特より 9 侍迄の間，即] ち就業 10 時間前後の 2 回につき 3 日間に亘り 101 名 に就て前述の方法で測定した。年令は 16 才より 76 才 迄平均 41 才 6 ケ月である。

(口) 測 定 值

描写曲線について種々の方面より検討したが，最も 簡明な表現法として各体位に於ける第 5 腰椎と第 7 頸 椎を結ぶ直線を求めそれ等のなす角度を以て現わすと 前後屈は寿归後に於ては平均 6.4 度減少している。 更に $2 ， 3$ の項目に分つて観察すると表 3 の如く, 表 3

\begin{tabular}{|c|c|c|c|c|c|c|c|c|c|c|}
\hline & 前 & 愿 & 角 & 後 & 㑛 & 角 & \multirow[b]{2}{*}{ 合 計 } & \multirow{2}{*}{ 人員 $(\%)$} & \multirow[b]{2}{*}{ 本均年命 } \\
\hline & & 労働前 & 労働後 & 差 & 労働前 & 労働後 & 差 & & & \\
\hline 本 & 均 & $27.6^{\circ}$ & $23.9^{\circ}$ & $-3.7^{\circ}$ & $15.1^{\circ}$ & $12.4^{\circ}$ & $-2.7^{\circ}$ & $-6.4^{\circ}$ & $\begin{array}{c}101 \text { 名 } \\
(100 \%)\end{array}$ & 41.6才 \\
\hline 前 後 属 共 減 & 少 & $30.8^{\circ}$ & $22.1^{\circ}$ & $-8.7^{\circ}$ & $15.1^{\circ}$ & $10.5^{\circ}$ & $-4.6^{\circ}$ & $-13.4^{\circ}$ & $\begin{array}{l}53 \text { 名 } \\
(52 \%)\end{array}$ & 43.2 才 \\
\hline 後属減 & 少 & $23.4^{\circ}$ & $30.1^{\circ}$ & $+6.7^{\circ}$ & $17.8^{\circ}$ & $12.2^{\circ}$ & $-5.6^{\circ}$ & $+1.1^{\circ}$ & $\begin{array}{l}19 \text { 名 } \\
(19 \%)\end{array}$ & 39.1 才 \\
\hline 前屈 & 少 & $30.1^{\circ}$ & $20.0^{\circ}$ & $-10.1^{\circ}$ & $13.4^{\circ}$ & $15.7^{\circ}$ & $+2.3^{\circ}$ & $-7.8^{\circ}$ & $\begin{array}{c}20 \text { 名 } \\
(20 \%)\end{array}$ & 39.5才 \\
\hline 前 後 屈 共 增 & 大 & $22.2^{\circ}$ & $27.4^{\circ}$ & $+5.2^{\circ}$ & $10.8^{\circ}$ & $14.9^{\circ}$ & $+4.1^{\circ}$ & $+9.3^{\circ}$ & $\begin{array}{l}9 \text { 名 } \\
\text { ( } 9 \%)\end{array}$ & 42.1 才 \\
\hline
\end{tabular}


前, 後屈角共に減少するものは 53 名 (52\%) で，そ の角度平均は 13.4 度であり, 後屈だけ減少するるのは 19 名 $(19 \%)$ で平均すると 1.1 度增大している。前屈 だけ減少するるのは 20 名 $(20 \%)$ で平均 7.8 度の減 少がある。前後屈共逆偪大するものは 9 名 $(9 \%)$ で平均 9.3 度である。即ち春柱前後屈領域の減少する ものは 53 名で $(52 \%)$, 前屈の減少するもの 73 名(72 $\%)$, 後屈の減少するものは 72 名 $(71 \%)$ で約 $70 \%$ は考㺫後, 脊柱の可動性が減少を来して居り, 前後届 共或は前, 後屈の何れかが減少しているるのを合計 すると 92 名 (91\%) に達している。

\section{結語}

私以曲線定規を用いて春柱の前後屈領域を測定した が本法は胸腰椎の静止乙び運動の状態を観察するには 笑用的传有用な方法である。私は本法により農夫 101 名の麦刈り前後の春柱の可動領域を測定した。得たる 数值の統計的处理に欠げているが約 $70 \%$ 亿於て麦刚 後に可動域の減少がある。此の㮏な検查法及び数值は 農村腰痛の解明に 1 つの手がかりを与えるものと考兄 る。

\section{参考 交 献}

1) 掘美 浩 : 老人性脊柱彎曲と胸涪形の変化. 弘前医学稚誌， 5, 2, 137，162, 昭 29 .

2 ）飯野 三郎：「コルセット」の固定をしらべた 1つの試み. 整形外科, 4, 3, 昭 28 .

3 ) 後藤 鉄夫, 他 : 所謂根性坐骨神経痛の病理と 治潦. 臨床と研究, 31,11 , 炤和 29.

4) 伊藤 三郎 : 脊柱角度計依る食柱正常可動域 と其の病的例の 2,3 . 外科, $17,10,749$, 昭 30 ,
5 ) 久原 健三 : 老令者脊柱の形態立びに其の運動 性について. 日整誌, $7,1,139$, 昭 7 .

6 ) 後藤 基直 : 春柱の形態並びに其の運動性につ いて. 日整誌， $5,1 ， 82$, 昭 5 .

7 ) 後藤 基直 : 脊柱の運動性を諭じ「コルセット」 の研究に及ぶ”. 日整誌，5，5，387，昭 6 .

8 ）後藤 基直 : 脊柱の運動性を諭じ「コルモット」 の研究に及ぶ. 日整誌，5，4，322，昭 5 .

9 ）後藤 基直 : 脊柱の運動性を論じ「コルセット」 の研究に及ぶ. 日整誌, 6, 8, 昭36.

10) S. N. Eichenholtz and Victor Mayer: J. B. J. S., 37-A, 317, 1955.

11) 高木 憲太 : 春柱描军器. 日整誌, $5,5,387$, 昭 6 .

12）後藤 基直, 他 : 小学校坚童の脊柱運動性につ いて. 日整誌，9，99，昭 9 .

13) T. A Willis: Maris Back : 54, 1953.

\section{追 加}

\section{久大整形 石 橋 恒 夫}

只今演者が述べました様に私達の教室では同様な曲 線定規を使用し種々の疾患について替柱前後届運動を 観察していますのでこ〉に追加致します。

春柱の可動性計測には種々の器具が考案されていま すが私達の教空では飯野式脊柱角度計及びこの曲線定” 規を使用して和ります。

曲線定規による方法は演者と全く同様にして実施し ておりますが，その使用方法の簡便性とあいまつて亦 柱の前後屈運動をありのま〉記載出来る点特便利 であります。 